Agnieszka Sojka

Uniwersytet Jagielloński

\title{
Personalistyczno-komunitariański ${ }^{1}$ wymiar animacji społeczno-kulturalnej
}

Próba całościowego spojrzenia na zjawisko animacji społeczno-kulturalnej ujawnia co najmniej dwie rzeczywistości jej oglądu. Z jednej strony odsłaniają się przede wszystkim praktyczne aplikacje animacji w różnych obszarach życia społecznego, kulturowego, a ostatnio nawet jej zastosowania w szeroko rozumianej gospodarce poprzez realizacje projektów komercyjnych ${ }^{2}$. Z drugiej - wyraźnie zaznacza się trend teoretycznego myślenia o animacji i poszukiwania dla niej stosownego narzędzia, by można było uporządkować mnogość działań nazywanych animacyjnymi, a w ślad za tym skategoryzować je nie tylko w celu wyłonienia aparatury pojęciowej, lecz nade wszystko po to, by określić, co definiujemy jako animację oraz to, co jest nią tylko w zamiarze autora, częstokroć oryginalnego skądinąd projektu edukacyjnego czy też kulturowego.

\footnotetext{
${ }^{1}$ Określenie zaproponowane w tytule niniejszego artykułu zainspirowane zostało podczas dyskusji nad animacją społeczno-kulturalną i jej wspólnotowym wymiarem z dr hab. Anetą Gawkowską, adiunktem w Instytucie Socjologii UW, w ramach seminariów naukowych, odbywających się cyklicznie w Instytucie Filozofii i Socjologii PAN.

${ }^{2}$ Mam na myśli udane próby zastosowania wiedzy $\mathrm{z}$ animacji społeczno-kulturalnej $\mathrm{w}$ zarządzaniu projektami komercyjnymi $\mathrm{w}$ ramach autorskiego programu prowadzonego w Instytucie Pedagogiki UJ w latach 2012-2016 „Zastosowanie edukacji kreatywnej i animacji społeczno-kulturowej w biznesie. Staże dla animatorów w przemysłach kreatywnych". Wypracowana wówczas metodyka zaangażowania pod kryptonimem ANIMAGAME cieszyła się zainteresowaniem w tracie współpracy z przedstawicielami świata biznesu, ale też dowiodła możliwości transferu teoretycznej wiedzy z zakresu nauk społeczno-humanistycznych do gospodarki. Opisowi zarówno projektów, jak i samej metodyki poświęcam osobną publikację będącą aktualnie w przygotowaniu.
} 
Trzy perspektywy kształcenia animatora i jego kompetencji

Refleksja snuta przez pedagogów szczególnie w ostatnich latach nad sukcesami i porażkami animacji jako metody stosowanej w pracy animatorów, niekiedy niestety funkcjonującej tylko z nazwy, ogranicza się częstokroć do akademickich dyskusji, pozostających w sferze "pobożnych życzeń” tak wobec animacji społeczno-kulturalnej, jak i osoby samego animatora. Ewentualnie stwierdza się fakt stawiania zbyt wysokich wymagań wobec animatora, poprzez co jego rola może być niedookreślona, zbyt szeroka, gdy chodzi o sprecyzowanie konkretnych kompetencji, ale także można stwierdzić, że nie do końca jasny jest profil jego przygotowania do wykonywania przyszłego zawodu. Składa się na to między innymi fakt różnych perspektyw spojrzenia na wykładnię animacji, chociażby przez pryzmat antropologii kulturowej, socjologii czy też pedagogiki. Badania nad kompetencjami animatora i raport $\mathrm{z}$ nich przygotowany pod auspicjami Małopolskiego Instytutu Kultury w Krakowie ${ }^{3}$, a poprzedzony dyskusją na Forum Kraków wyraźnie określiły kilka jego wzorców. Ukazanie animatora z perspektywy trzech wymienionych wyżej obszarów zwraca uwagę na jego kompetencje z uwzględnieniem owych perspektyw, które znacząco różnicują jego rolę. I tak można mówić o profilu kształcenia animatora kultury z perspektywy socjologicznej, kulturoznawczej oraz pedagogicznej, bowiem proces kształcenia animatora dokonuje się na wymienionych kierunkach studiów w wielu ośrodkach akademickich. Zwróćmy uwagę, że na kierunku socjologia częstokroć uprawiana jest ona $\mathrm{w}$ ramach pracy socjalnej dostarczającej wiedzy normatywnej. W ujęciu pedagogicznym może nabrać waloru wychowawczego i w takiej perspektywie może być rozumiana jako cel działań wychowawczych, metoda czy technika wykorzystywana w pracy pedagogicznej (w węższym znaczeniu wychowawczej), ale również może funkcjonować jako jedna $\mathrm{z}$ zasad pedagogiki ${ }^{5}$. Zawarta jest ona w postulacie nieustannego „ożywiania” procesów nauczania i wychowania. Animowanie owych procesów miałoby wpływać na ich efektywność. W końcu, przyjmując wykładnię antropologii kulturowej, stykamy się z animacją kultury czynnej, doświadczanej na co dzień, wręcz zanurzonej w codzienności. W propozycji antropologicznej animacja występuje jako narzędzie stosowanej antropologii kulturowej, „która posługując

${ }^{3} \mathrm{~W}$ ramach projektu „Animacja/Edukacja. Możliwości i ograniczenia animacji i edukacji kulturowej w Polsce", zrealizowanego w latach 2013-2014 przez Małopolski Instytut Kultury, przeprowadzono badania, w toku których wyłoniono trzy typy animatorów: miłośników kultury, zakorzenionych i metropolitarnych profesjonalistów.

${ }^{4}$ Cykliczne dwudniowe spotkania Stowarzyszenia Forum Kraków działającego przy MIK w Krakowie podejmujące teoretyczno-praktyczne problemy animacji i edukacji kulturowej oraz poświęcone organizacji takich wydarzeń jak chociażby NieKongres Animatorów Kultury (Warszawa 2014, Wrocław-Brzeg 2016).

${ }^{5} \mathrm{O}$ dwóch pierwszych przytoczonych traktuje literatura przedmiotu, trzecia propozycja wynika $z$ analizy i interpretacji badań własnych nad animacją, czemu między innymi poświęcona jest osobna monografia przygotowywana do druku. 
się różnymi metodami odtwarza pamięć i przeszłość, poszukuje rozumienia fenomenów kultury, przecina podział na kulturę wysoką i niską" (Krasowska 2013: 14). Według prowadzących kształcenie animatorów w Instytucie Kultury Polskiej w Uniwersytecie Warszawskim antropologiczna perspektywa animacji dokonuje oglądu działania kulturalnego z punktu widzenia wzorów i postaw, stosunków społecznych, tradycji i środowiska lokalnego. Wobec tego istotne dla animatora jest poznanie historycznej i społecznej specyfiki miejsca prowadzenia działań oraz charakteru i oczekiwań społeczności, z którą współpracuje ${ }^{6}$. W zaproponowanym w niniejszym artykule personalistyczno-komunitariańskim ujęciu wszystkie trzy podejścia do animacji są konieczne, by zaszły animacyjne procesy prowadzące do zmiany społecznej. Jak bowiem mogłoby w działaniach takich zabraknąć norm, wartości, czy też odwołania się do czynienia kultury na co dzień?

W niniejszym artykule zgłaszam potrzebę stawiania pytań o istotę animacji społeczno-kulturalnej oraz czynienia refleksji nad nią nie tylko przez animatora, ale i kadr kształcących przyszłych animatorów, a także przygotowujących do pełnienia owej roli w społecznościach lokalnych. Proponuję również autorskie ujęcie jednego z wymiarów animacji, jakim jest jej personalistyczno-komunitariański charakter.

Stawiam niepodważalną tezę, że wciąż zaznacza się brak badań istotnościowych nad animacją, stąd też tak łatwo o wyroki skazujące ją samą oraz jej zastosowanie na niepowodzenie. Jak już wspomniałam w pierwszym akapitach niniejszego artykułu, dyskusje akademickie nad animacją społeczno-kulturalną pobrzmiewają głosami o nieodniesionym przez nią oczekiwanym sukcesie choć, jak wiemy, od co najmniej ćwierćwiecza zadomowiła się ona w rzeczywistości polskiej, wręcz stając się reklamą różnych instytucji. Zważmy jednak na fakt nadużywania określenia „animacyjny” we wszelkich projektach z zakresu kultury czy szerzej rozumianej społecznej działalności człowieka i nakierowanych na człowieka. Nie powinien dziwić zatem brak konkretnych efektów, nazwijmy je animacyjnymi, w dosłownym tego słowa znaczeniu „ożywiającymi”, bowiem te wymagają szczególnego nastawienia animatora i wynikającego z niego podejścia do uczestnika działań animacyjnych. Efektem mogłoby być, zawarte w nazwie, zobowiązujące "poruszenie wewnętrzne", na podstawie którego może dojść do trwałej zmiany w osobowości danej jednostki. Mamy na uwadze zmianę postaw przejawiających się w zachowaniach a także w konkretnych decyzjach i idących za nimi działaniach podejmowanych na rzecz środowiska lokalnego. Tak sformułowana myśl otwierać może pole do badań nad efektami zabiegów animacyjnych, bowiem podjęcie ich wydaje się konieczne, jeśli chcemy nadal uprawiać animację społeczno-kulturową i rozwiązać problem jej skuteczności chociażby w dziedzinie pedagogiki. Pomocne byłoby tu fenomenologiczne podejście do badań nad interesującym nas przedmiotem, które przede wszystkim stwarza możliwość istotnościowego opisu animacji społeczno-kulturowej. Poprzez zaproponowany w tytule niniejszego artykułu wymiar

\footnotetext{
${ }^{6}$ Cf. stanowisko Zofii Dworakowskiej dotyczące kompetencji animatora kultury kształconych w IKP UW, http://forumkrakow.info/wp-content/uploads/Kompetencje-animatora-IKP-UW.pdf.
} 
personalistyczno-komunitariański animacji wskazuję na potencjał zawarty w źródłosłowie samego pojęcia i próby wykorzystania go w pracy z człowiekiem poprzez wartości zawarte w dobrach kultury. Tym samym, nawiązując do zamiarów twórców niniejszego tomu „Ars Educandi”, można wskazywać z jednej strony na społeczno-kulturowe uwarunkowania, jakim podlega nie tylko animator, ale i animowany, a z drugiej - na możliwości przezwyciężania pewnych ograniczeń wynikających z owych determinant. Postrzegając animację przez jej personalistyczno-komunitariański charakter, mamy na uwadze rozwój i funkcjonowanie człowieka nie tylko jako osoby mającej niepowtarzalny zestrój cech, a wśród nich między innymi wydobywane $\mathrm{w}$ procesie animacji zdolności, tak zwane talenty, ale i jako członka większej grupy, w konfrontacji z którą zauważa swą odrębność, cechy zarówno jednostkowe, jak i wspólne. Jedne jak i drugie konstytuują pełnię jego człowieczeństwa rozumianą jako świadome aktualizowanie swoich możliwości, a poprzez nie - przekraczanie wszelkich ograniczeń. Odkrywa się ona przed człowiekiem, a zarazem odkrywana jest przez niego samego, w trakcie animacyjnych działań czy to poprzez świat wartości kultury, czy przez szeroko rozumiane działania na rzecz społeczeństwa mające na celu między innymi zmianę jakości życia poszczególnych grup. Zaznaczmy, że to ostatnie wymaga szczególnej wrażliwości na tak zwanego Innego/Obcego, polegającej na swoistym wsłuchiwaniu się $\mathrm{w}$ jego indywidualne potrzeby i odkrywaniu ich wraz z nim, a może opierającej się wręcz tylko na dyskretnym towarzyszeniu mu w odnajdywaniu przez niego samego autentycznych potrzeb własnych. Zwróćmy uwagę, że tkwią one dużo głębiej niż na poziomie zaspokojenia materialnych potrzeb. Zapewne też są wtórne wobec dostarczonych/zaspokojonych uprzednio wartości/potrzeb podstawowych, jak na przykład witalnych, odnoszących się do zwykłych codziennych czynności życiowych oraz zdrowia fizycznego i psychicznego.

Nietrudno zatem zauważyć rysujący się humanistyczno-społeczny charakter przyszłych absolwentów animacji, kształcących się szczególnie na kierunku pedagogika oraz kulturoznawstwo, a także szeroki, aczkolwiek nie dość pogłębiony, zakres wiedzy teoretycznej dostarczanej im w procesie kształcenia ${ }^{7}$. W tym właśnie przejawia się powyżej wspomniany charakter kształcenia animatorów, bowiem oprócz dogłębnej wiedzy z zakresu pedagogiki, w przypadku tej pierwszej otrzymują jedynie podstawy psychologii i socjologii, a także rudymentarną wiedzę dotyczącą dziedzin sztuki (plastyki, muzyki, teatru, literatury, filmu).

Tak jak istotne są wiedza i u miejętności animatora w różnorodnych dziedzinach, tak samo ważni są mistrzowie, u których terminują przyszli animatorzy. Zatem warto podejmować refleksje nie tylko nad procesem kształcenia, kompetencjami,

\footnotetext{
${ }^{7}$ Problematykę katalogowania kompetencji animatora i oglądu animacji z perspektywy pedagogicznej podjęłam $\mathrm{w}$ artykule przygotowanym dla przedstawienia stanowiska w tej sprawie na Forum Kraków działającym przy MIK. W niniejszym szkicu wykorzystuję wątki tam podjęte, przytaczając niektóre z nich w całości, http://forumkrakow.info/blog/2015/04/13/ kompetencje-animatorow-kultury-stanowisko-forum-krakow/.
} 
lecz także i samą wartością pracy animatora, dochodząc tym samym do istoty animacji społeczno-kulturalnej. Wykładając wiedzę teoretyczną traktującą o animacji społeczno-kulturalnej, a także ucząc animatorów praktycznego jej zastosowania w trakcie kilkuletniego procesu kształcenia akademickiego, może warto zastanowić się również nad byciem autentycznym animatorem - rozpoznającym talenty, a zarazem mądrze je ukierunkowującym, towarzyszącym wychowawcą $\mathrm{w}$ procesie zarządzania już rozpoznanymi? Pojawią się tym samym niezbędne w pracy animatora kompetencje, tak zwane animacyjne, w zakresie ożywiania, inspirowania otaczającej rzeczywistości określające kluczowy wymiar profesjonalnych postaw animatora wyrażających się w otwartości, refleksyjności, świadomości ulepszania duchowego człowieka, a nie tylko podnoszenia biologicznych sprawności organi$\mathrm{zmu}$, a także inwestowania $\mathrm{w}$ duchowy potencjał wychowanka. W takim rozumieniu animacja może zaradzać manipulacjom czy kolonizacjom.

\section{Od osoby do wspólnoty w działaniach animacyjnych}

Spojrzenie na animację społeczno-kulturalną poprzez zaproponowany wymiar personalistyczno-komunitariański koresponduje $\mathrm{z}$ antropologią kulturową, gdzie animacja nade wszystko stanowi wyraz poszukiwania rozumienia fenomenów kultury, a postrzegana jako idea sprzeciwia się technokratycznemu ujęciu kultury masowej, mającemu wpływ na osobowość kulturową i typy więzi międzyludzkich (Mencwel 2002: 20). Wkomponowuje się w co najmniej dwa elementy stanowiące rdzeń personalistyczno-komunitariańskiego jej wymiaru, a mianowicie osobę i wspólnotę. Zatem zwróćmy uwagę, że istnienie osób wolnych i twórczych nieodwołalnie wiąże się w sieć społecznych uwarunkowań, jak twierdził Emmanuel Mounier twórca otwartego personalizmu, a zarazem założyciel pisma „Esprit” związanego $\mathrm{z}$ nurtem animacji we Francji. W myśl komunitarianizmu tożsamość jednostki jest pochodną tradycji, przyswajanych przez nią w toku socjalizacji i funkcji społecznych, jakie pełni. Jednostka w ujęciu komunitariańskim jest częścią wspólnot otaczających ją i poprzez nie realizuje siebie jako indywiduum. W odróżnieniu od liberalizmu komunitaryzm kładzie nacisk nie tyle na niezależność i prawa jednostki, ile na jej związki i obowiązki społeczne, a także wspólne wartości, które są niezbędne do przetrwania społeczeństwa. To, kim jesteśmy, zależy nie tylko od nas, nie jest jedynie kwestią indywidualnego wyboru, jak twierdzą liberałowie, ale jest uwarunkowane wielością związków łączących nas z innymi członkami wspólnoty, „horyzontem wspólnych znaczeń”. Ta wspólna przestrzeń wyznacza również sens pojęć, którymi się posługujemy. Nie sposób zrozumieć, czym jest sprawiedliwość, tolerancja, wolność poza kontekstem znaczeniowym właściwym każdej wspólnocie. Ochrona kultury i tożsamości zbiorowej jest niezbędna do ochrony i rozwoju ,ja" osadzonego w zbiorowych praktykach. Utożsamienie obywateli z państwem i wspólnotą polityczną dokonać się może tylko 
tam, gdzie są cenione „wspólnotowe formy życia”, a ich trwanie i kondycja mają jedynie znaczenie wyłącznie instrumentalne i nie służą zaspokojeniu indywidualnych potrzeb. Wspólnota jest dobrem koniecznym dla jednostek i dlatego, zdaniem komunitarian, powinna być chroniona przez państwo. Komunitarianie dostrzegają we współczesnych społeczeństwach zachodnich silne tendencje atomizacyjne, obywatelską apatię, wycofanie się w prywatność, głębokie rozwarstwienia kulturowo-społeczne. Uważają, że dla zachowania tożsamości zbiorowej i wzmocnienia społecznych więzi niezbędne jest przywrócenie ducha demokratycznego współuczestnictwa przez ożywienie i rozwój społeczeństwa obywatelskiego oraz decentralizację struktur państwowych. Animacja w swej istocie zawiera potencjał wspólnototwórczy, a jako metoda czy technika skutecznego działania może wzmacniać więzi międzyludzkie, w ich ramach komunikację, a tym samym budować mocne wspólnoty, co rozwijam w dalszej części artykułu.

Utopijna wydaje się przytoczona powyżej myśl, a jednak praktyka dnia codziennego potwierdza istnienie konkretnych miejsc, w których animacja rozumiana jako idea, postawa, styl życia, ale również metoda, jest uprawiana, i można dostrzec obserwowalne/empiryczne wskaźniki zachodzących dzięki niej zmian. Myślą przewodnią tak rozumianej, a zarazem uprawianej, animacji przez historyków i teoretyków kultury jest odkrywanie twórczych możliwości, zarówno $\mathrm{u}$ siebie samych, jak i innych. Uczenie wrażliwości na potencjał ukryty w drugim człowieku, empatia wobec uczuć innego oraz szczególny wgląd w rozumienie jego umysłu to główne umiejętności kształcone w ramach specjalizacji „animacja kultury" w rozumieniu antropologii stosowanej. W jednym ze znanych francuskich czasopism poświęconych animacji autor artykułu dotyczącego antropologicznego kontekstu pracy animatora określił źródła trwałości i spójności animacji jako tkwiące w życiu codziennym mieszkańców społeczności lokalnych (Precas 1984: 117). Potwierdza to francuski badacz animacji Pierre Besnard, domagając się nieograniczania jej jedynie do instrumentalnych czynności wykonywanych podczas czasu wolnego w procesie upowszechniania kultury ( $v$. Besnard 1980).

W tym miejscu można przywołać ukryty spór w środowiskach uprawiających animację, a dotykający, może nawet nieświadomie, jej istoty, mianowicie korzeni, statusu ontologicznego i nadbudowanych nad nimi paradygmatów jej rozumienia, a co za tym idzie stosowania. Chodzi tu o wskazanie edukacyjnego horyzontu animacji i to niezależnie od przypisanego jej określenia „społeczno-kulturalna/kulturowa”, czy też „kultury”. Andrzej Mencwel wykazuje to w swoim tekście, mówiąc o celu przedsięwzięć animacyjnych, ale dodając, jaką edukację ma na myśli: „nastawiona na indywidualizację, subiektywizację, kreację" (Mencwel 2002: 22). Autor używa sformułowania charakterystycznego dla pedagogiki, jakim jest "prowadzenie”, nazywając intencję towarzyszącą celowi powołania specjalizacji przy Katedrze Kultury Polskiej Uniwersytetu Warszawskiego. Czasowniki „ożywiać”, „prowadzić” łączy z czynnością animowania.

Próbując odpowiedzieć na pytanie: czym jest animacja dla pedagogiki?, poszukuję jej korzeni, by móc sprawniej poruszać się w jej zasięgu, czy też znaleźć dla niej 
podstawy teoretyczne. Mencwel wymienia następujące działania w polu animacyjnych procesów: pobudzanie twórczości, kształtowanie osobowości, tworzenie konkretnych więzi (Mencwel 2002: 25). W procesie animacji rozpoczynamy od uważnego przyjrzenia się jej uczestnikom i skupieniu na nich uwagi, by zainteresować działaniem, a poprzez to zaangażować w ruch czy to społeczny, czy twórczy. $\mathrm{W}$ tym miejscu warto przywołać jedno $\mathrm{z}$ wielu stanowisk teoretycznych badaczy francuskich i polskich wskazujących opisywany tu wychowawczy potencjał animacji. I tak wspomniany już Besnard (1988: 341-376) mówi o pobudzaniu jednostki do działania, wprowadzaniu jej w środowisko i integrowaniu z szerszymi strukturami, co implikuje procesy inkluzji.

\section{„Duch” personalizmu i komunitaryzmu w animacji społeczno-kulturowej}

Rozważania nad „ożywiającym” potencjałem animacji społeczno-kulturalnej nabierają głębszego znaczenia, gdy włączymy je w zaproponowany w niniejszym artykule wymiar personalistyczno-komunitariański ${ }^{8}$. Przyglądając się jego ideologicznym korzeniom, można wyraźnie dostrzec trzy klasyczne nurty, z których czerpie. Wyłonione po Rewolucji Francuskiej: konserwatyzm, liberalizm i socjalizm inspirują opisywany tu wymiar. Odwołujący się do nich, ale i podejmujący krytyczną dyskusję personalizm a następnie komunitarianizm proponują wizję osoby „zanurzonej” w relacje $\mathrm{z}$ innymi w ramach różnego rodzaju wspólnot. Wartością naczelną $\mathrm{w}$ tym przypadku jest różnorodnie pojęte, ale z założenia istniejące dobro wspólne, które legitymizuje działania animacyjne. Wymiar ów pojawia się jako nowe dodatkowe źródło uprawomocnienia działań animacyjnych poprzez istnienie obiektywnego dobra wspólnego, co powoduje, że zmiana dokonywana w osobie czy grupie pod wpływem podjętych działań animacyjnych nie jest narzucaniem czegoś z zewnątrz, ale odwołuje się do wewnętrznych potrzeb uczestników w trakcie trwania procesu animacyjnego. Tym samym nie chodzi tu nawet o ożywianie tego, co umarło, lecz pobudzenie tego, co jest, co istnieje, jednakże będącego jak gdyby w letargu, w stanie uśpienia. Tym samym dotykamy istoty człowieczeństwa, bowiem, sięgając do wewnątrz, wydobywamy to, co winno zostać ujawnione. Dokonuje się to poprzez wewnętrzne nastawienie jednostki do przemiany, przez swoisty przymus wewnętrzny w odróżnieniu od zewnętrznego,

\footnotetext{
${ }^{8}$ Zaproponowany tu wymiar animacji społeczno-kulturalnej ujawnił się w trakcie badań własnych prowadzonych nad zastosowaniem metodyki animacji społeczno-kulturowej w projektach aktywizacji osób z zaburzeniami psychicznymi oraz prób ich aktywizacji społecznej i zawodowej. Pierwszych opisów personalistyczno-komunitariańskiego wymiaru animacji dokonałam w artykule poświęconym zrealizowanemu projektowi z wyżej wymienionego zakresu. W niniejszym wykorzystuję, a zarazem pogłębiam, analizę zaproponowanego w tytule artykułu wymiaru animacji.
} 
o czym pisał Bogdan Nawroczyński, równoważąc w wychowaniu tak potrzebne przymus i swobodę (1987). Działania animacyjne mogą sprzyjać swoistemu przeobrażaniu się przymusu przychodzącego $\mathrm{z}$ zewnątrz $\mathrm{w}$ wewnętrznie zinternalizowany system nakazów, które stają się motorem rozwoju jednostki i grup. Najprostsze przykłady to działania animacyjne w amatorskim ruchu artystycznym, które wiążą się częstokroć z dużą dozą wysiłku, wręcz poświęcenia ze strony uczestników, a jednak $\mathrm{z}$ takim przekonaniem wykonywanych, że jasne jest, że wynikają $\mathrm{z}$ równowagi przymusu zewnętrznego i wewnętrznego.

Rozpatrując działania animacyjne $\mathrm{w}$ zaproponowanej powyżej perspektywie personalistyczno-komunitariańskiej, można stwierdzić, że wspólnota rozwija się w świecie własnych relacji, jednakże animacja gwarantuje budowanie szerszych struktur, rozprzestrzenianie się relacji (Gawkowska 2004b). Mamy tym samym na uwadze silne wspólnoty charakteryzujące się mocnym zakorzenieniem, identyfikacją członków społeczności w określonej przestrzeni, maksimum więzi bezpośrednich lub „zrzeszeń” wyznaczonych przez racjonalną, ale fragmentaryczną logikę celu (Kurczewska 2004: 93). Pytanie o istnienie społeczności lokalnej w czasach współczesnych przenosi się na obszar poszukiwania zbiorów powiązanych ze sobą jednostek o wspólnej tożsamości, mieszkających na określonym obszarze, uznających typowy dla społeczności zbiór norm i zasad, mających bezpośredni kontakt, współdziałających na rzecz wspólnego dobra, ale korzystających też z kontaktów ze światem zewnętrznym. Odnajdywaniu ich pomaga myślenie o społecznościach lokalnych ukazane przez Joannę Kurczewską w opozycjach: czasu i przestrzeni, inkluzji i ekskluzji, wspólnoty i zrzeszenia, lokalności i globalności (Kurczewska 2004: 90). Problemem kolejnym i jakże istotnym w tym momencie jest pytanie o rolę animacji społeczno-kulturalnej we wspomaganiu procesu tworzenia się lokalnej społeczności, czy może, jak najczęściej pisze się o tym w literaturze przedmiotu, działanie w ramach już istniejącej i przeobrażanie jej w tak zwaną silną wspólnotę.

Termin animować oznaczający między innymi „ożywiać”, metaforycznie ujmowany jako „tchnąć życie”, związany jest z działaniami wspólnotowymi. Animacja skierowana jest do grupy osób znajdujących się w sytuacji zdarzenia kulturalnego, edukacyjnego o charakterze społecznym. Wymiar wspólnotowy działalności animacyjnej polega na integracji grup uczestników imprez kulturalnych, w wydarzeniach mających szeroki zasięg społeczny, które pełnią również rolę edukacyjną w kręgu wyrażanych przez grupę wartości. Wszelkie działania mają zawsze charakter relacyjny, są skierowane na drugiego, wobec którego je podejmujemy. Każdy podjęty przez nas czyn ma konsekwencje $\mathrm{w}$ życiu otaczających nas osób, a animacja społeczno-kulturalna ściśle powiązana ze środowiskiem lokalnym skutkuje w pracy z małą grupą, a także z jednostką ludzką.

Wyłania się zatem, wywołany powyższymi pytaniami, problem budowania wspólnoty poprzez działania animacyjne łączący się z ideą komunitaryzmu. Propozycję taką zgłosiła Aneta Gawkowska poprzez zastosowanie koncepcji komunitarystycznych do opisu i analizy lokalnych działań aktywizujących z wykorzystaniem 
działań z obszaru kultury w społecznościach lokalnych (2004b) ${ }^{9}$. Szczególną uwagę należy skupić na aksjologicznym kontekście tworzenia owej wspólnoty.

$\mathrm{W}$ poddawanych animacyjnym działaniom grupom wybrzmiewa pytanie: jak uczynić wspólnotę z grupy osób? Wspólnotę, której istnienie zakłada: równość członków polegającą na zapewnieniu każdemu maksymalnego rozwoju, wolność rozumianą jako dokonywanie wyborów z poszanowaniem i uznaniem prawa wolnego wyboru drugiego człowieka, bezwarunkową akceptację sprzyjającą przemianie wewnętrznej, wspólne dzielenie się, wzajemność. W obecnym świecie, który charakteryzuje się fragmentaryzacją w każdej właściwie sferze życia, jest to jedno z poważniejszych wyzwań dla pedagogów - animatorów kultury, a zarazem problem wychowawczy. Działania animacyjne z założenia mające „ożywić” jednostkę i całe grupy ludzkie są szczególnego rodzaju aktywnością, która stwarza możliwości budowania wspólnot między ludźmi.

Animacja uruchamia procesy dotyczące tego, co dzieje się teraz, dokonując pozytywnej wizji przyszłości. Procesy implikowane przez animację, takie jak: odkrywanie, tworzenie związków oraz twórczośćc ${ }^{10}$ odnajdujemy na etapie rozpoznania częstokroć niedostrzeżonych wcześniej talentów i umiejętnym pokierowaniu nimi, kolejno na wytwarzaniu związków na płaszczyźnie wspólnych zainteresowań, ale i wspólnoty przeżyć doświadczanych w trakcie podejmowanych działań animacyjnych w większych grupach osób. Tworzenie warunków do rozwoju osób, ze szczególnym uwzględnieniem Innego/Obcego, rozpoznawanie w osobach poddawanych procesom animacyjnych ukrytych możliwości twórczych oraz potrzeb kulturalnych to pierwszy z procesów - odkrywanie. Sfera komunikacji międzyludzkiej oraz wartości zawartych w dobrach kultury, w które wprowadzane są osoby animowane $\mathrm{w}$ trakcie kontaktu $\mathrm{z}$ dziełem sztuki, to następny $\mathrm{z}$ omawianych procesów - tworzenie związków. Znana $\mathrm{z}$ literatury przedmiotu etapami zachodząca animacja nabiera nowego kształtu w kontekście zaproponowanego w niniejszym artykule personalistyczno-komunitariańskiego wymiaru animacji. Uwypukla cechy indywidualne, szczególnie skupiając się na ujawnianych potencjalnych zdolnościach jednostki, by w następstwie spoić je z wartościami wspólnotowymi. Ów animacyjny proces dokonuje się w taki sposób, by podkreślić wyjątkowość i niezbędność cech indywidualnych każdej osoby dla czynienia z grupy przypadkowych osób wspólnoty.

${ }^{9}$ Więcej na temat teorii komunitarystycznych v. A. Gawkowska, Biorąc wspólnote poważnie? Komunitarystyczne krytyki liberalizmu, Warszawa 2004, Wydawnictwo IFiS PAN. Anglojęzyczna wersja książki: Taking Community Seriously? Communitarian Critiques of Liberalism, Warsaw 2011, Warsaw University Press, .

${ }^{10}$ Między innymi: Fundacja Sztuki Osób Niepełnosprawnych, Fundacja „Hamlet”, Stowarzyszenie Pomocy Socjalnej „Gaudium”, Fundacja im. Brata Alberta, Stowarzyszenie GRAAL na rzecz rozwoju osobowości dzieci, Fundacja MAXIMUM, w których realizowano projekty animacyjne.

${ }^{16}$ Mamy na myśli procesy wyodrębnione przez H. Therry; H. Therry, Animation, action sociale, action culturelle, „Recherche Sociale” 1970, No. 32. 
Podsumowując powyższe rozważania, należy jeszcze raz podkreślić, że intencją autorki było nade wszystko otwarcie nowych pól badawczych w obliczu rodzących się wątpliwości co do istnienia i funkcjonowania animacji społeczno-kulturalnej zarówno w środowisku teoretyków, jak i praktyków poszukujących odpowiedzi na pytanie: czym jest animacja społeczno-kulturowa i na jakie sposoby uprawiać ją, by odkryć i wykorzystać w pełni jej potencjał, zawarty nie tylko w atrakcyjnych formach działania, ale i ukryty w znaczeniu samego pojęcia? Poprzez zarysowanie zaproponowanego $\mathrm{w}$ tytule niniejszego artykułu personalistyczno-komunitariańskiego wymiaru animacji zwraca się uwagę na jej istotę. Zawiera się ona między innymi w tym, że animacja, pracując w polu indywidualnych oczekiwań, wykracza poza nie, ujawniając wspólnotowy charakter, by w efekcie stać się instrumentem inkluzji społecznej.

\section{Literatura}

Besnard P., 1980, L'animation socio-culturelle, Paris: PUF.

Besnard P., 1988, Problematyka animacji społeczno-kulturalnej [w:] Rozprawy o wychowaniu, t. 2, red. M. Debesse, G. Mialaret, tłum. Z. Zakrzewska, Warszawa: PWN.

Folkierska A., 2005, Sergiusz Hessen - pedagog odpowiedzialny, Warszawa: Wydawnictwa Uniwersytetu Warszawskiego.

Gajda J., 2000, Pedagogika kultury w zarysie, Kraków: Impuls.

Gawkowska A., 2004a, Biorac wspólnotę poważnie? Komunitarystyczne krytyki liberalizmu, Warszawa: Wydawnictwo IFiS PAN.

Gawkowska A., 2004b, O korzyściach teoretycznych i praktycznych ze wspólnotowości, „Kultura współczesna” nr 4.

Gawkowska A., 2011, Taking Community Seriously? Communitarian Critiques of Liberalism, Warsaw: Warsaw University Press.

Husserl E., 1967, Idee czystej fenomenologii i fenomenologicznej filozofii, thum. D. Gierulanka, Kraków: PWN.

Krasowska A., 2013, Animator w domu kultury. Studium socjologiczne, Wrocław: SKiBA.

Kunowski S., 1981, Podstawy wspótczesnej pedagogiki, Łódź: Wydawnictwo Salezjańskie.

Kurczewska J., 2004, Robocze ideologie lokalności. Stare i nowe schematy [w:] eadem, Oblicza lokalności Tradycja i współczesność, Warszawa: Instytut Filozofii i Socjologii PAN.

Nawroczyński B., 1987, Dzieła wybrane, t. 1, wybór, oprac. wstęp A. Mońka-Stanikowa, Warszawa: Wydawnictwa Szkolne i Pedagogiczne.

Mencwel A., 2002, Przyczyniać się pomału [w:] Animacja kultury. Doświadczenie i przyszłość, red. G. Godlewski et al., Warszawa: Instytut Kultury Polskiej UW.

Precas N., 1984, Pour une approche antropologique du metier de l'animateur, „Cahiers de l'Animation" No. 44-45.

Sojka A., 2005, Wspólnotowy wymiar animacji kultury [w:] Kultura jako fundament wspólnoty edukacyjnej, red. A. Sajdak, Kraków: WUJ.

Therry H., 1970, Animation, action sociale, action culturelle, „Recherche Sociale” No. 32. 
Abstrakt

W niniejszym artykule zgłaszam potrzebę stawiania pytań o istotę animacji społeczno-kulturalnej oraz dokonywania refleksji nad nią nie tylko przez animatora, ale i kadry kształcące przyszłych animatorów, a także przygotowujące do pełnienia owej roli w społecznościach lokalnych. Proponuję również autorskie ujęcie jednego z wymiarów animacji, jakim jest jej personalistyczno-komunitariański charakter. Rozważania owe wpisuję w ogólną tematykę aktualnego tomu „Ars Educandi”, podejmując zagadnienie uwarunkowań rozwoju i funkcjonowania człowieka (w tym wypadku animatora i animowanego), szczególnie interesujących mnie determinant społeczno-kulturowych.

\section{Słowa kluczowe}

animacja społeczno-kulturalna, umiejętności i wiedza animatorów, kompetencje animatorów, edukacja animatorów, jednostka, wspólnota

\section{Summary}

\section{Personalism and communitarians idea in social and cultural animation}

Nowadays the culture activity is one of the most important topics which need to take approach to the problem. This article aims to address the issue by showing how essential is to constitute new groups are increasingly conscious of a bound of unity. It is step in the direction of integration and concentration on the common values. It seems to be an interesting problem not only for pedagogues but for everyone who is engaged in social-culture animation. Most variety of ideas presented in this article can inspire many readers.

\section{Keywords}

the social-culture animation, cultural activity, skills and knowledge of animators, education of animators, community 